Chirurgia (2020) 115: 469-475

No. 4, July - August

Copyright@ Celsius

http://dx.doi.org/10.21614/chirurgia.115.4.469

\title{
Do We Really Know How Much the Covid-19 Pandemic Affected the Surgical Practice in Northern Italy? A Multi-Center Comparative Study and Cost Analysis
}

\author{
Giulio Mari', Rosario Giordano ${ }^{1 *}$, Matteo Uccelli², Giovanni Cesana'2 ${ }^{2}$, Stefano Olmi' Giovanni Carlo Ferrari ${ }^{3}$, \\ Matteo Origi ${ }^{3}$, Dario Maggioni', Gaia Colletti ${ }^{4}$, Andrea Costanzi ${ }^{4}$, On behalf of AIMS Academy Clinical Research Network ${ }^{5}$
}

${ }^{1}$ General Surgery Unit Asst Monza Desio Hospital, Italy

${ }^{2}$ General Surgery Unit Policlinico S. Marco Zingonia, Italy

${ }^{3}$ General Surgery Unit Asst Grande Ospedale Metropolitano Niguarda, Milano, Italy

${ }^{4}$ General Surgery Unit Ospedale San Leopoldo Mandic ASST Lecco Merate, Italy

${ }^{5}$ www.aimsacademy.org

*Corresponding author:

Rosario Giordano, MD

Via mazzini 3 Desio 20832 Italy

E-mail: ros.giord93@gmail.com

\section{Rezumat}

Știm cu adevărat cât de mult a afectat pandemia Covid-19 practica chirurgicală în Italia de Nord?

Un studiu comparativ cu mai multe centre și analiza costurilor

Introducere: Pandemia Covid-19 din Italia de nord-est a încetinit activitatea chirurgicală clinică. A fost instituit un sistem de spitale cu noduri şi vorbe pentru îngrijirea pacienților oncologici, dar cu abolirea aproape completă a activității chirurgicale elective pentru patologii non onologice.

Metode: Am analizat retrospectiv volumele chirurgicale ale 4 spitale generale academice din Lombardia aparținând la 4 provincii diferite. Trimestrul martie-aprilie-mai 2019 a fost comparat cu aceeaşi perioadă a anului 2020. Au fost listate toate procedurile diferite. Analiza costurilor a fost realizată cu ajutorul sistemului DRG.

Rezultate:În cele patru spitale s-au realizat proceduri chirurgicale reduse de la 1903 la 350 cu o scădere de 81,6\%. Proceduri pentru cancer de la 403 la 161 cu o scădere de 60,1\%. Proceduri pentru boala benignă de la 1310 la 118 cu o scădere de $91 \%$. Urgențe de la 190 la 71 cu o scădere de $62,6 \%$. Rambursarea de la stat pentru procedurile efectuate de la 6.708.023 € la 1.678.154 € cu o scădere de $75 \%$.

Concluzii: Chirurgia electivă pentru pacienții non-oncologici nonurgenți a fost afectată dramatic de pandemia Covid-19. Mai presus de toate procedurile pentru pacienții non-oncologici şi non-urgenți 
au fost afectați în special. Având în vedere o posibilă a doua undă a pandemiei, planificarea chirurgicală trebuie să selectiveze pacienții nu numai pe criterii oncologice, ci mai degrabă pe cele clinice. O cale ad hoc şi o cale de spitale de vorbire trebuie să fie implementate pentru bolile chirurgicale benigne de către oricine se confruntă cu pandemia Covid la vârful său.

Cuvinte cheie: chirurgie, pandemie Covid-19, analiză costuri

\begin{abstract}
Background: The Covid-19 pandemic in Northern Italy has slowed down the clinical surgical activity. A system of hub and spoke hospitals was set up to take care of oncological patients with the consequent almost complete abolition of the elective surgical activity for non-oncological pathologies.

Methods: We retrospectively analyzed the surgical volumes of 4 different non academic general hospitals in Lombardy belonging to 4 different provinces. The quarter March April May 2019 was compared with the same period of 2020. All different procedures were listed. The cost analysis was performed using the DRG system.

Results: In the four hospitals involved the surgical procedures reduced from 1903 to 350 with a drop of the $81.6 \%$. Procedures for cancer from 403 to 161 with a drop of $60.1 \%$. Procedures for benign disease from 1310 to 118 with a drop of the $91 \%$. Emergencies from 190 to 71 with a drop of the $62.6 \%$. State refund for the procedures performed from $6.708 .023 €$ to $1.678 .154 €$ with a drop of $75 \%$.

Conclusions: Elective surgery was dramatically impaired by the Covid-19 pandemic. Above all procedures for non oncological and non urgent patients were particularly affected. In view of a possible second wave of the pandemic, the surgical planning must select patients not only on oncological criteria but rather on clinical ones. An ad hoc hub and spoke hospitals pathway has to be implemented for benign surgical diseases by whoever is facing the Covid pandemic at its spike.
\end{abstract}

Key words: surgery, Covid19 pandemic, cost analysis

\section{Introduction}

The Covid-19 pandemic in northern Italy in the quarter March April May 2020 has requested the deployment of all available health resources of Lombardy, Northern Italy (1). The daily clinical activity has therefore slowed down to respond only to the undeferrable clinical needs. The reduction of the clinical activity meant to treat only oncological and urgent patients allowed almost all the doctors and nurses to devote themselves to the care of Covid patients (2).

Although inevitable, this redistribution of healthcare resources has delayed the treatments for a huge number of patients.
Especially in the surgical field, as elective operations were cancelled, surgeons have been performing only emergency or oncological surgery (3).

Efforts have been made to keep cancer surgery active by setting up a system of hub and spoke hospitals to take care of oncological patients (4).

However one relevant consequence of the pandemic was the almost complete abolition of the elective surgical activity for nononcological pathologies (5).

Of note that this latter represents the majority of the pathologies treated by general hospitals in Lombardy. It comes clear how such a situation is deeply affecting the whole population awaiting for surgery and it is 
generating a consistent drop in the hospital's surgical efficiency. However, although perceived, a precise quantification of the delayed procedures and of what that means in terms of loss of economic revenue has not been assessed.

Aim of this study was to determinate to which extent the surgical procedures for cancer, benign pathologies and emergencies were affected by the Covid 19 pandemic. The secondary aim of this study was to perform a cost analysis of the two quarters analyzed to assess the impact of the Covid 19 pandemic on the services provided.

\section{Methods}

We retrospectively analyzed the surgical volumes of 4 different non academic general hospitals in Lombardy belonging to 4 different provinces.

The four hospitals are non academic high volume public regional hospitals admitting patients from emergency room and from outpatients departement. The four hospitals have different sizes ranging from 1100 beds to 300 beds. All of them admit patients for elective abdominal, breast and endocrine oncological diseases, benign abdominal disease, abdominal wall defects, pathological obesity as well as emergencies from the emergency rooms.

During the Covid pandemic, the four hospitals analyzed were completely converted to treat covid patients. All wards became Covid wards and operating rooms were transformed into intensive care units. Each hospital maintained the essential minimum number of "clean" beds to be able to handle emergencies. The converting process has been recently described (6). The quarter March April May 2019 was compared with the same period of 2020 regarding only non Covid patients. When it was not possible to handle oncological patients in a reasonable time, patients were traferred through a hub and spoke hospitals pathway (4). Data were collected from the surgical registries of each hospital. All different procedures were listed. The cost analysis was performed using the Diagnosis related Group DRG system of Lombardy Regional Health
Service (7). A diagnosis-related group-based prospective payment system operates across the country and accounts for most hospital revenue. However, hospitals run directly by local health units typically have global budgets. Rates include all hospital expenses, including physician salaries, and costs for expensive technologies and medicines. Public funds are allocated by local health units to public and accredited private hospitals (7).

The reimbursement for each procedure performed was therefore calculated in order to obtain the overall difference between the two quarters analyzed and the month-to-month differences. All Diagnosis related Group (DRG) of the two periods were considered "un-complicated" to better even the data obtained. In the Italian setting the DRGs describe the complexity of the clinical care of the in-hospital acute patients through the definition of categories of clinically significant and homogeneous hospitalizations and the resources absorbed. Therefore they can be considered the main tool for determining the amount of funding to be allocated to each hospital.

The procedures performed were then divided into procedures for cancer, benign pathology and emergencies in order to determine the progresses of the different types of surgery performed.

The description of the data collected was provided in terms of absolute volumes and in percentages. The differences between the two quarters analyzed are given in absolute numbers providing the reduction in percentages.

The analysis performed were approved by the local ethical committees

\section{Results}

In the 2019 March- April- May quarter in the four hospitals involved in the study 1903 surgical procedures were performed while in the same period in 2020 only 350 procedures were performed with a reduction of the $81.6 \%$. Procedures for cancer dropped down from 403 to 161 in the same period with a reduction of $60.1 \%$. Procedures for benign disease were 
Table 1.

\begin{tabular}{lccccccc}
\hline & 2019 quarter & $\mathbf{2 0 2 0}$ quarter & $\begin{array}{c}\text { Reduction } \\
\text { in\% }\end{array}$ & Refund & Refund & $\begin{array}{c}\text { Reduction } \\
\text { in\% }\end{array}$ \\
\hline Procedures for cancer & 403 & 161 & 60 & 2.265 .155 & 967.333 & 57,3 \\
\hline Procedures for benign diseases & 1310 & 118 & 91 & 3.794 .222 & 387404 & 89,8 \\
\hline Emergencies & 190 & 71 & 62,6 & 648.646 & 323.417 & 50,1 \\
\hline Total procedures & 1903 & 350 & 81,6 & 6.708 .023 & 1.678 .154 & 75 \\
\hline
\end{tabular}

1310 in the 2019 March- April- May quarter and only 118 in the same period in 2020 with a reduction of the $91 \%$. Emergencies as well reduced from 190 to 71 with a reduction of the $62.6 \%$ (Table 1).

State refund for the procedures performed in the 2019 quarter was 6.708.023 euro and 1.678.154 euro in the 2020 quarter with a reduction of $75 \%$ (Fig. 1).

Of note, the reductions in percentage of the procedures performed in March 2020, April 2020, May 2020 compared to those performed in 2019 were $84.4 \%, 88,9 \%$ and $72 \%$ respectively showing an improving trend towards the end of the pandemic.

On the same line, the reduction of the pro- cedures for cancer moved from $64.5 \%$ of March 2020 vs March 2019 to $41.5 \%$ of May 2020 vs May 2019 and similarly the reduction of the procedures for benign disease moved from $94.1 \%$ of March 2020 vs March 2019 to $82.8 \%$ of May 2020 vs May 2019 (Table 2).

All the high volume oncological surgical procedures ( $>10$ per month) had a decrease in percentage waving from the $36.7 \%$ (pancreatectomies) to $74.2 \%$ (breast cancer procedures). However looking at the surgical procedures for benign disease, the reductions in terms of absolute volumes is definitively higher reaching 95.8\% for hernia repair, $81.3 \%$ for cholecystectomy, $94.7 \%$ for bariatric procedures and $92.4 \%$ for hemorroidectomy (Table 3).

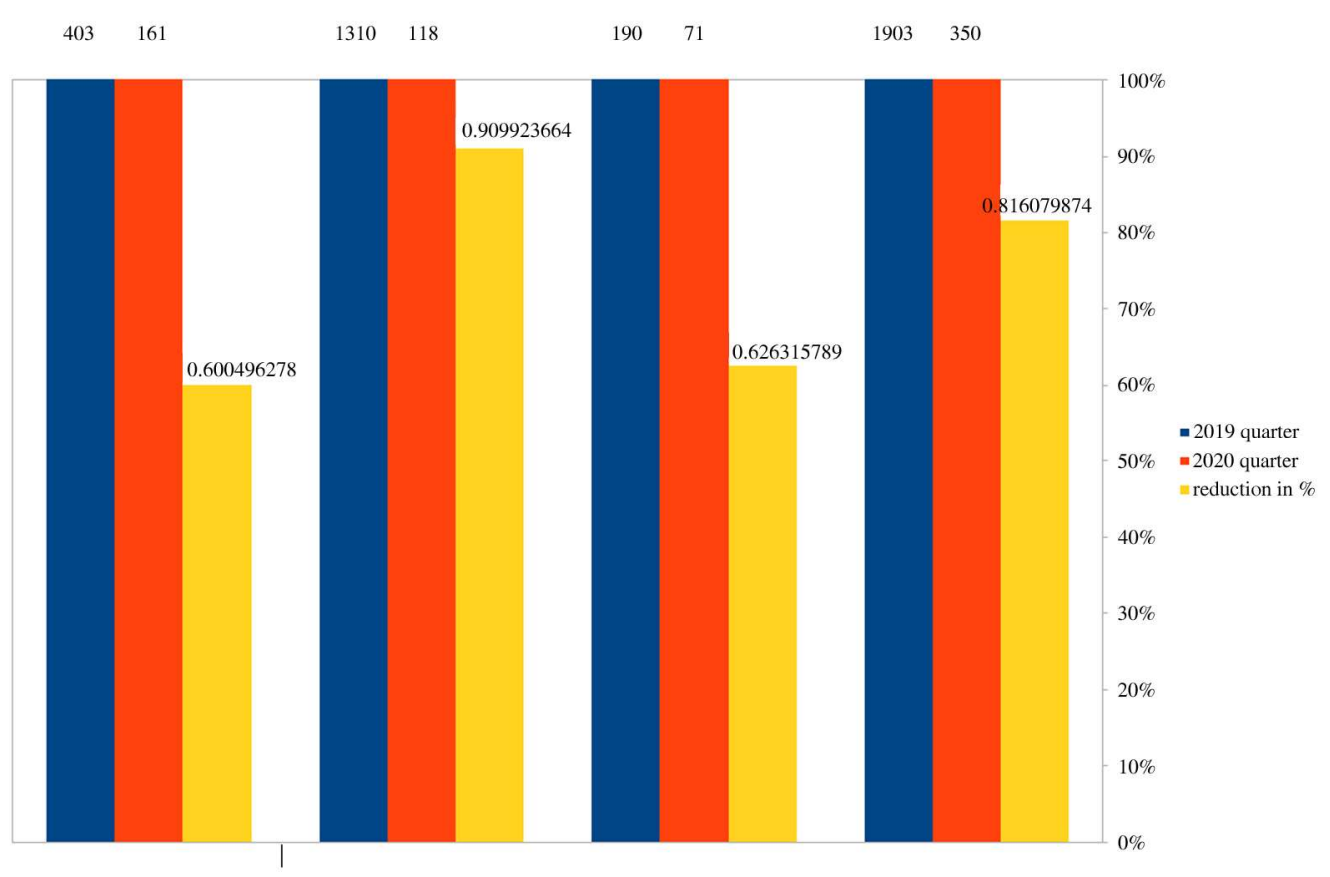

Figure 1. Difference in procedures number 
Table 2. Procedures performed per month

\begin{tabular}{lccc}
\hline & March 2019 & March 2020 & Reduction in\% \\
\hline Procedures for cancer & 138 & 49 & 64,5 \\
\hline Procedures for benign diseases & 475 & 28 & 94,1 \\
\hline Emergencies & 61 & 29 & 52,5 \\
\hline Total procedures & 674 & 105 & 84,4 \\
\hline & April 2019 & April 2020 & \\
\hline Procedures for cancer & 135 & 36 & 73,3 \\
\hline Procedures for benign diseases & 392 & 14 & 96,4 \\
\hline Emergencies & 66 & 16 & 75,8 \\
\hline Total procedures & 593 & 66 & 88,9 \\
\hline & May 2019 & May 2020 & 41,5 \\
\hline Procedures for cancer & 130 & 76 & 82,8 \\
\hline Procedures for benign diseases & 443 & 76 & 58,7 \\
\hline Emergencies & 63 & 26 & 72 \\
\hline Total & 636 & 178 & \\
\hline
\end{tabular}

Table 3. Types of procedures performed

\begin{tabular}{|c|c|c|c|c|}
\hline & & Quarter 2019 & Quarter 2020 & $\begin{array}{c}\text { Reduction } \\
\text { in } \%\end{array}$ \\
\hline \multirow[t]{11}{*}{ Procedures for cancer } & & 403 & 161 & 60 \\
\hline & Rectal resection & 29 & 12 & 58,6 \\
\hline & Left Hemicolectomy & 64 & 25 & 60,9 \\
\hline & Right hemicolectomy & 54 & 17 & 68,5 \\
\hline & Gastrectomy & 39 & 20 & 48,7 \\
\hline & Brest surgery & 128 & 33 & 74,2 \\
\hline & Esophagectomy & 6 & 6 & 0 \\
\hline & Hepatectomy & 18 & 8 & 55,6 \\
\hline & Adrenalectomy & 15 & 2 & 86,7 \\
\hline & Pancreatectomy & 30 & 19 & 36,7 \\
\hline & Lymphadenectomy & 17 & 14 & 17,6 \\
\hline \multirow[t]{10}{*}{ Procedures for bening disease } & & 1310 & 118 & 91 \\
\hline & hernia repair & 355 & 15 & 95,8 \\
\hline & Cholecystectomy & 193 & 36 & 81,3 \\
\hline & Diverticulitis & 22 & 7 & 68,2 \\
\hline & Thyroidectomy & 119 & 19 & 84 \\
\hline & Bariatric procedures & 393 & 21 & 94,7 \\
\hline & hemorroidectomy & 119 & 9 & 92,4 \\
\hline & Splenectomy & 11 & 3 & 72,7 \\
\hline & Jatal hernia repair & 11 & 2 & 81,8 \\
\hline & Minor surgery & 61 & 4 & 93,4 \\
\hline \multirow[t]{9}{*}{ Emergencies } & & 190 & 71 & 62,6 \\
\hline & Appendectomy & 42 & 27 & 35,7 \\
\hline & Small bowel resection & 10 & 4 & 60 \\
\hline & Colonic resection & 21 & 4 & 81 \\
\hline & Cholecystectomy & 14 & 14 & 0 \\
\hline & Gastric perforation & 5 & 1 & 80 \\
\hline & Trapped hernia & 9 & 1 & 88,9 \\
\hline & Peri-anal abscess & 54 & 2 & 96,3 \\
\hline & Intestinal occlusions & 35 & 32 & 8,6 \\
\hline
\end{tabular}




\section{Discussion}

The Covid-19 pandemic has negatively affected the surgical activity worldwide (8). The outbreak of the pandemic in Northern Italy has overwhelmed the critical care resources such as intensive care unit beds and mechanical ventilation capability. Italy in fact in the March-April-May 2020 quarter declared a national emergency. Hospitals therefore changed their workflows according to the Italian Healthcare System guidelines meant to prevent the virus spread and to rationalize personal protective equipment (PPE). All nonurgent outpatient activities and surgical procedures for benign disease were stopped $(1,2)$. On-call duties, emergency surgery and oncological procedures were maintained through a hub and spoke hospitals pathway.

The consequent reduction of the general surgical practice has been almost total.

Most of the data in the literature on surgical activity during the Covid-19 pandemic are "perceptions described" (9). However, the real quantification of the decrease of the surgical practice is often not reported.

The data we report were collected from four general hospitals belonging to four different Lombardy provinces. They are therefore reliable in terms of heterogeneity. All the centers involved were entirely dedicated to assisting Covid-19 patients during the pandemic and therefore suffered from the same precarious conditions of the surgical departments.

Surgery for benign pathology has been the most affected by the Covid-19 pandemic. Surgery for cancer in fact has been better preserved in all hospitals. In addition the hub and spoke path for oncological patients filled the gap of each center (10). Unfortunately none of this has been thought for benign surgical diseases, although clinically relevant (11). The same hub and spoke path built for cancer patients in fact should also have been prepared for non-cancer patients but with pathologies that could become urgent.

Postponing the surgical activity for benign pathology exposes patients to the risk of worsening their clinical condition to the point of becoming "urgent" patients. It is well known how operating on an urgent critical patient increases the risk of post-operative ICU need, thus reducing the availability of respiratory assistance for COVID patients (12).

The drop in urgent procedures performed has also been described by other authors and is partially inexplicable. Surely during the Covid-19 pandemic, the overall number of patients presenting to the ER with surgical pathologies decreased significantly although we do not have ad hoc data (13). One possible explanation is that patients avoided coming to ER for fear of the pandemic. However this does not clarify how pathologies normally present in the population did not generate urgent clinical frameworks.

The economic impact of the collapse of the surgical activity on hospitals will surely have consequences on the balance sheets, making the economic planning of the next period even more difficult (14). The forecast of the budget deficit of the hospitals in the covid pandemic is difficult to be quantified. Hospitals in fact received a refound for each Covid patient. However, such reimbursement can hardly compensate for the loss occurred. To date, a structured plan for the future surgical activity to be increased to compensate the need of the patients is yet to be provided although advisable.

This study (15) has several limitations. It is a pure retrospective study analyzing a relatively short period of time. It was performed during the Covid pandemic and the data collection could have been somehow affected by the unprecedented situation. Statistical analysis is purely comparative. However this study clearly describes through a data collection how the Covid pandemic has affected the elective surgical practice in Italy.

\section{Conclusion}

We firmly believe that the ongoing situation regarding elective surgery would not be sustainable for longer. In view of a possible second wave of the Covid pandemic, the 
surgical planning must be redesigned by selecting patients not only on the basis of an oncological criterion but rather on the basis of a clinical criterion. In fact for example an early stage colonic or rectal cancer could have a lesser vital impact then a severe diverticulitis or a giant symptomatic hiatal hernia An ad hoc hub and spoke hospitals pathway has to be implemented for benign surgical diseases by whoever is facing the Covid pandemic at its spike.

\section{Disclosures}

There was no funding for this study. All authors decleare they have nothing to disclose.

\section{References}

1. Arolfo S, Velluti F, Romagnoli R, Lo Secco G, Allaix ME, Morino M. COVID-19 outbreak and the practice of surgery: do we need to change? Br J Surg. 2020;10.1002/bjs.11763. Online ahead of print.

2. Bernardi L, Germani P, Del Zotto G, Scotton G, De Manzini N, Impact of COVID-19 Pandemic on General Surgery Training Program: An Italian Experience. Am J Surg. 2020;S00029610(20)30363-9.

3. Patriti A, Baiocchi GL, Catena F, Marini P, Catarci M. FACS on behalf of the Associazione Chirurghi Ospedalieri Italiani (ACOI) Emergency General Surgery in Italy During the COVID-19 Outbreak: First Survey From the Real Life. World J Emerg Surg 2020;15(1):36.

4. Butler J, Finley C, Norell CH, Harrison S, Bryant $\mathrm{H}$, Achiam MP, et al. New approaches to cancer care in a COVID-19 world. Lancet Oncol. 2020 Jul;21(7):e339-e340
5. Lima DL, Pereira X, Dos Santos DC, Camacho D, Malcher F, Where are the hernias? A paradoxical decrease in emergency hernia surgery during COVID-19 pandemic. Hernia. 2020;1-2. Online ahead of print.

6. Mari G, Crippa J, Casciaro F, Maggioni D. A 10-step guide to convert a surgical unit into a COVID-19 unit during the COVID-19 pandemic. Int J Surg. 2020;78:113-114.

7. Ferre $F$, de Belvis AG, Valerio L, Longhi S, Lazzari A, Fattore G, et al. Italy: Health System Review. Health Syst Transit. 2014;16(4):1-168.

8. Al-Shamsi HO, Alhazzani W, Alhuraiji A, Coomes EA, Chemaly RF, Almuhanna M, et al. A Practical Approach to the Management of Cancer Patients During the Novel Coronavirus Disease 2019 (COVID-19) Pandemic: An International Collaborative Group. Oncologist. 2020;25(6):e936-e945.

9. Anteby R, Zage $Y$, Barash $Y$, Nadler R, Cordoba M, Klang E, et al. The impact of the coronavirus disease 2019 outbreak on the attendance of patients with surgical complaints at a tertiary hospital emergency department. J Laparoendosc Adv Surg Tech A. 2020. Online ahead of print.

10. Harky A, Chun Ming Chiu, Ho Lai Yau T, Sheung Heng Daniel Lai. Cancer Patient Care During COVID-19. Cancer Cell. 2020;37(6):749750.

11. Kassir R, Rebibo L, Genser L, Sterker A, Blanchet M-C, Pattou F, et al. SOFFCO-MM Guidelines for the resumption of bariatric and metabolic surgery during and after the Covid-19 pandemic. J Visc Surg. 2020;S1878-7886(20)30154-5.

12. Patel R, Hainsworth AJ, Devlin K, Patel JH, Karim A. Frequency and severity of general surgical emergencies during the COVID-19 pandemic: single-centre experience from a large metropolitan teaching hospital. Ann R Coll Surg Engl. 2020;1-6.

13. Patriti A, Eugeni E, Guerra F. What happened to surgical emergencies in the era of COVID-19 outbreak? Considerations of surgeons working in an Italian COVID-19 red zone. Updates Surg. 2020;72(2):309-310.

14. Best MJ, Aziz KT, McFarland EG, Anderson GF, Srikumaran U Economic implications of decreased elective orthopaedic and musculoskeletal surgery volume during the coronavirus disease 2019 pandemic. Int Orthop. 2020;1-8. Online ahead of print

15. COVIDSurg Collaborative. Elective surgery cancellations due to the COVID-19 pandemic: global predictive modelling to inform surgical recovery plans. Br J Surg. 2020;10.1002/bjs.11746. Online ahead of print. 